\title{
Improving the Quality of Life after Radiotherapy
}

Liana Svampane, MD PhD, Ella Nesterenko, MD, Evita Puspure, MD

Riga East University Hospital, Oncology Centre of Latvia

Aim. To periodically study the repair of vaginal mucous membrane for patients after radiotherapy.

Materials and methods. The study includes 63 patients after a regimen of radiotherapy, using it as the only and primary method of treatment including postoperative radiotherapy.

\section{Distribution of patients by age}

\begin{tabular}{|c|c|c|c|c|c|c|}
\hline $\begin{array}{c}\text { Patient } \\
\text { age }\end{array}$ & $30-39$ & $40-49$ & $50-59$ & $60-69$ & $70-79$ & $80+$ \\
\hline $\begin{array}{c}\text { Patient } \\
\text { count }\end{array}$ & 7 & 9 & 18 & 20 & 6 & 3 \\
\hline
\end{tabular}

\section{Results.}

After receiving radiotherapy the patients had three follow-up visits:

- after 1 month;

- after 4 months;

- after 7 months.

\begin{tabular}{|c|c|}
\hline Type of therapy & Patient Count \\
\hline 3D conformal radiotherapy & 33 \\
\hline $\begin{array}{c}\text { Combined radiotherapy (3D } \\
\text { conformal and cavity therapy) }\end{array}$ & 28 \\
\hline Cavity therapy & 2 \\
\hline
\end{tabular}

Further treatment was appointed depending on the type of administered radiotherapy and evaluating local changes after therapy. Local changes like colpitis or vaginitis were observed after combined radiotherapy. Therefore, first vaginal capsules were administered to locally treat gynaecological inflammations. Twelve patients received such local therapy after combined radiotherapy. Afterwards, Feminella suppositories were administered according to the following schedule: 1 per day for 10 days, continue 3 per week for 3 months and 2 per week for 3 more months.
Follow-up after 1 month:

\begin{tabular}{|c|c|}
\hline $\begin{array}{c}\text { Response after treating with } \\
\text { Feminella }\end{array}$ & Patient Count \\
\hline $\begin{array}{c}\text { Completely normal mucous } \\
\text { membrane }\end{array}$ & 28 \\
\hline Local changes in inflammation & 30 \\
\hline Dropouts & 5 \\
\hline
\end{tabular}

Follow-up after 4 months:

\begin{tabular}{|c|c|}
\hline $\begin{array}{c}\text { Response after treating with } \\
\text { Feminella }\end{array}$ & Patient Count \\
\hline $\begin{array}{c}\text { Completely normal mucous } \\
\text { membrane }\end{array}$ & $37(28+9)$ \\
\hline Local changes in inflammation & 21 \\
\hline Dropouts & 5 \\
\hline
\end{tabular}

Follow-up after 7 months:

\begin{tabular}{|c|c|}
\hline $\begin{array}{c}\text { Response after treating with } \\
\text { Feminella }\end{array}$ & Patient Count \\
\hline $\begin{array}{c}\text { Completely normal mucous } \\
\text { membrane }\end{array}$ & $40(28+9+3)$ \\
\hline Local changes in inflammation & 18 \\
\hline Dropouts & 5 \\
\hline
\end{tabular}

Conclusion. Feminella suppositories are suitable for vaginal mucous membrane repair and the improvement of quality of life after radiotherapy, including the reduction of local vaginal inflammation and improvement of urination and sexual functions. 